\title{
Spatial Dynamics between Firm Sales and Environmental Responsibility: The Mediating Role of Corporate Innovation
}

\author{
Jiafeng Gu 10
}

Citation: Gu, J. Spatial Dynamics between Firm Sales and Environmental Responsibility: The Mediating Role of Corporate Innovation. Sustainability 2021, 13, 1684. https://doi.org/10.3390/ su13041684

Academic Editor: Lorenzo Ardito

Received: 8 January 2021

Accepted: 2 February 2021

Published: 4 February 2021

Publisher's Note: MDPI stays neutral with regard to jurisdictional claims in published maps and institutional affiliations.

Copyright: (C) 2021 by the author. Licensee MDPI, Basel, Switzerland. This article is an open access article distributed under the terms and conditions of the Creative Commons Attribution (CC BY) license (https:/ / creativecommons.org/licenses/by/ $4.0 /)$.
Institute of Social Survey Study, Peking University, Beijing 100871, China; isssgujf@pku.edu.cn; Tel.: +86-10-62767908-881

\begin{abstract}
Corporate environmental responsibility (CER) is increasingly gaining interest among researchers and practitioners. Despite this extensive interest, systematic research regarding the effect of sales on environmental performance remains scarce. In this study, an empirical analysis on a sample of 909 Chinese listed companies from 2010 to 2016 showed that sales positively impact environmental performance. This study also showed that corporate innovation mediates the relationship between sales and environmental performance. Furthermore, this study showed that environmental performance has a positive spatial spillover effect. Enterprises appear to promote their own environmental performance as a response to a rise in the environmental performance of their neighbors. The external control theory of organization has important reference significance and explanatory power for CER behavior in emerging economies.
\end{abstract}

Keywords: corporate environmental responsibility; firm sales; environmental performance; corporate innovation; mediating effect

\section{Introduction}

After the two industrial revolutions, the serious "resource curse" caused by enterprises in their production and operation processes has become a topic of significant concern in the world today [1]. In such a scenario, the environmental responsibility practices of an enterprise are conducive for acquiring more resources by improving efficiency and improving their innovation capabilities and financial performance [2,3]. Moreover, such practices can enhance the enthusiasm of the sales team and effectively enhance the sales force of enterprises [4]. Past studies have mostly focused on the impact of corporate environmental responsibility (CER) on innovation and sales [5,6]. However, there is a lack of research on how sales influence CER through innovation. It is important to better understand the mechanisms within enterprises that foster why and how firms behave environmentally to improve firm performance [7].

Furthermore, CER is affected by external environmental factors such as the laws and regulations formulated by governments [8], the public's environmental awareness [9], local economic development, and mass media attention $[10,11]$. Moreover, there are frequent spatial dependencies and strategic interactions of CER practices between neighboring companies [12]. A positive spatial spillover effect may exist in CER practices [13]. However, to the best of our knowledge, this has been ignored in the CER literature. CER practices have drawn substantial interest from practitioners and academics. However, the factors driving these practices have received little attention in the academic literature.

Since the reform, China's economy has continued to grow rapidly, and it is now the world's second-largest economy and the world's largest emerging economy. In this process, the strength of Chinese companies has also been greatly improved. Chinese companies actively participate in social responsibility activities, and their contribution and influence to society are also increasing. In this emerging economy, it has gradually become a common phenomenon that enterprises take the initiative to assume social responsibility. 
In a certain sense, corporate environmental responsibility, a kind of social responsibility and obligation that society entrusts to Chinese companies, is rapidly rising, and it deserves people's attention [14]. Chinese companies often have certain Chinese characteristics when they undertake environmental responsibilities. However, the current research on CER in emerging economies is still lacking, which is not commensurate with the status of emerging economies in the world.

Against this backdrop, this article contributes to our growing understanding of the determinants of CER by examining how CER performance reacts to sales. Using Chinese listed companies as the research sample, our main research questions are as follows: What impact will sales have on CER performance? What kind of transmission mechanism exists between sales and CER performance? Is there a spatial spillover effect in CER activities between neighboring companies? Compared with the existing research, the contribution of this article is mainly reflected in two aspects. First, this research not only analyzes the impact of sales on CER but also explores the intermediate transmission mechanism between them. Second, this study uses panel data to analyze the spatial dynamics mechanism of sales regarding CER and explores the spatial spillover effects of CER activities.

The rest of the article is organized as follows. Section 2 describes the analytic framework. Section 3 presents the data. Section 4 provides quantitative research results and discussion. Section 5 presents the conclusions of this study.

\section{Literature Review and Hypotheses Development}

\subsection{Literature Review}

CER refers to the corporate social responsibility (CSR) for ecological environmental protection within an enterprise's process of maximizing its own profits $[15,16]$. Enterprises should not be developed at the cost of the ecological environment [17]. Enterprises must abide by relevant laws and regulations and protect the ecological environment $[18,19]$.

Past studies have mostly focused on the impact of CER on corporate performance $[5,6]$. This kind of research has a basic implicit logic: CER will affect the market performance of enterprises through a certain mechanism [20]. This is a way to study CER behavior and its impact from the internal perspective of the enterprise. According to the external control theory of organization, the behavior of an organization is best understood by analyzing the environmental context of that behavior [21-23]. External control system is the general term for external control mechanisms that can be used to achieve corporate governance goals. It includes law, product and factor market competition, reputation market, etc. For example, corporate environmental information disclosure is largely due to pressure from external governments, consumers, and competitors [24]. Thus, in CER research, it is important to focus on the effect of the environment on firms' CER and, in turn, on how firms respond to external constraints via CER. In the study of CER, an important question is whether the market recognizes CER's value [25]. CER activities may have positive or negative consequences on firm performance [26-28]. Given the prevalence of sales as a form of market-recognized value of CER, it is surprising that the CER literature pays so little attention to sales. It is important to investigate the antecedents of good firm environmental performance [29].

Recent studies do discuss the impact of CER on sales. However, the impact of sales on CER has been ignored [5,6]. Since the impact mechanism of sales on CER is unclear, this has led to insufficient investment in CER [30]. As the public's awareness of environmental protection continues to increase, environmental factors have an increasing influence on the competitiveness of enterprises. Furthermore, CER is the most important non-price, competitiveness factor of products [31]. Consumers are willing to pay more premium for environmentally-friendly products [32], and thus consumers can influence the CER behavior of enterprises $[33,34]$. Therefore, it is necessary to study CER from the perspective of consumers. Furthermore, consumers' willingness to buy will be reflected in the company's sales. Together, these points highlight the importance of investigating the influence mechanism of sales on CER. 


\subsection{Hypotheses Development}

Companies with good sales performance tend to pay more attention to consumer preferences [35]. When consumers are more willing to buy products from companies with a good CER reputation, the marketing department will promptly pass this information to the company's decision-making level to promote the company's investment in CER [36-38]. CER practices can create a positive and trustworthy image for consumers [39]. Companies with good sales performance are more willing to continue with increasing investment in CER, and thereby, eliminate consumers' dissatisfaction [40].

Moreover, companies with good sales performance pay more attention to sustainable development [41]. CER is an important guarantee for enterprises to achieve sustainable development [10,42]. CER is also an important component of corporate brand building, which enhances the brand appeal to consumers [43]. To continuously strengthen the brand's appeal to consumers, companies with good performance will continue to increase investment in CER [44]. Thus, CER is an important guarantee of corporate reputation $[45,46]$. On the contrary, for companies with poor sales performance, the cost of CER will constitute a burden $[47,48]$. Therefore, companies with poor sales performance will generally reduce the CER input as much as possible [30]. This idea is expressed in this hypothesis as follows:

Hypothesis 1 (H1). Sales will have a positive effect on environmental performance.

There is a mediating effect between sales and CSR [4]. In addition, corporate innovation plays a mediating role in the relationship between CER and firm value [28]. Corporate innovation is considered as a cumulative and dynamic knowledge system that leads to the transfer and diffusion of ideas, knowledge, learning, and economic development $[49,50]$. As a mediating variable, corporate innovation acts as the "transformation engine" between sales and CER performance. To realize this function, two connections are needed:

Corporate innovation-CER performance relationship. In the relevant research on corporate innovation and CER performance, Ziegler et al. [51] used listed companies in the European capital market as a sample to study the impact of green innovation behavior on CER performance. The authors found that corporate innovation can significantly help companies gain more lower-cost capital to invest in environmental protection. Berchicci et al. [52] used listed U.S. manufacturing companies as a sample and found that innovation by companies can significantly help companies obtain various preferential policies for environmental protection from relevant government departments. This enhances companies' motivation to increase investments in environmental protection. Corporate innovation can create value for customers, reduce environmental pollution, and conserve resources [53,54]. Corporate innovation can strengthen CER performance by improving product and service quality $[20,55]$. Thus, corporate innovation is an important driver of CER performance.

Firm sales-corporate innovation relationship. The concepts of market orientation and corporate innovation are steadily gaining ground in an increasingly competitive environment [56,57]. Firms' R\&D expenditures are approximately unit elastic with respect to increases in their revenues from sales [58]. The proportion of innovation expenditure to sales revenue is an important decision indicator for determining investments in innovation $[59,60]$. Once this indicator is determined, the sales revenue directly determines the company's investment in innovation. The higher the company's sales, the higher the innovation investments [61]. Companies with good sales performance are more willing to invest in environmental technology innovation and then transform this innovation into a market success [62]. There is often a positive correlation between corporate environmental innovation and sales revenue [63]. Thus, an increase in market sales induces corporate innovation.

This reasoning leads us to propose a mediating process by which sales affect CER performance through corporate innovation. It makes sense to hypothesize that the reason sales impact CER performance is because sales affect corporate innovation, which is a 
critical determinant of the CER outcomes the firm achieves. This idea is expressed in this hypothesis as follows:

Hypothesis $\mathbf{2}(\mathbf{H} 2)$. Corporate innovation will mediate the relationship between sales and environmental performance.

This hypothesis includes the following two sub-hypotheses:

Hypothesis 2a (H2a). Corporate innovation will have a positive effect on environmental performance.

Hypothesis $\mathbf{2 b} \mathbf{( H 2 b )}$. Sales will have a positive effect on corporate innovation.

With the continuous improvement in consumers' awareness of environmental protection, CER activities are no longer just a peripheral practice to enterprises. They are also important strategies for enterprises to obtain competitive advantages [64,65]. Actively protecting the environment during the operation of a company has not only become a corporate responsibility but, more importantly, an important strategy for enhancing market competitiveness [66]. Companies that take the lead in environmental innovation will enjoy "first-mover advantage" in the market and can sell products at higher prices, improve their corporate image, and even create new markets [67]. Moreover, as a differentiated competitive strategy, CER can attract cheap funding sources and retain talent for companies [68]. There is a direct and positive relationship between the adoption of environmental practices and the company's competitive position [69]. Because CER has such a strategic significance, to gain a competitive advantage, companies will formulate their own CER strategy based on the opponent's CER strategy, thereby forming a CER game [70-72]. Therefore, there will be strategic interactions between these companies. Furthermore, enterprises will behave strategically in making spending decisions regarding environmental protection [73,74].

In the CSR game, when a company achieves good CSR performance, competitors will follow suit and increase investment in CSR to achieve better results [75]. In other words, CSR behavior has a positive spillover effect [76,77]. According to Tobler's First Law of Geography, everything is related to everything else, but near things are more related to each other [78]. This spillover effect of CER between neighboring companies is often more obvious. Neighboring competitors do not want to fall behind in the CER game. Therefore, they will rush to increase CSR investment and improve CSR performance. CER activities have the so-called geographic localization characteristics [79]. Enterprises appear to increase their own CER spending as a response to an increase in environmental protection spending by their neighbors [12]. This is the positive spatial spillover effect $[80,81]$.

To test this spatial spillover effect, a spatial lag of explained variable is introduced into the empirical model [82]. Here, when the spatial lag of CER performance is considered, there is a spatial spillover effect if the effect of the spatial lag is significant [83]. The CER performance of a company could be influenced positively by the CER performance in its neighboring companies [12,79]. It means that there is a significant spatial lag term indicating a positive correlation between CER performance of a company and CER performance of "nearby" companies. This idea is expressed in this hypothesis as follows:

Hypothesis 3 (H3). Spatial lag of CER performance will have a positive effect on environmental performance.

Figure 1 shows a graphical representation of the proposed theoretical model and the research hypotheses to be tested. 


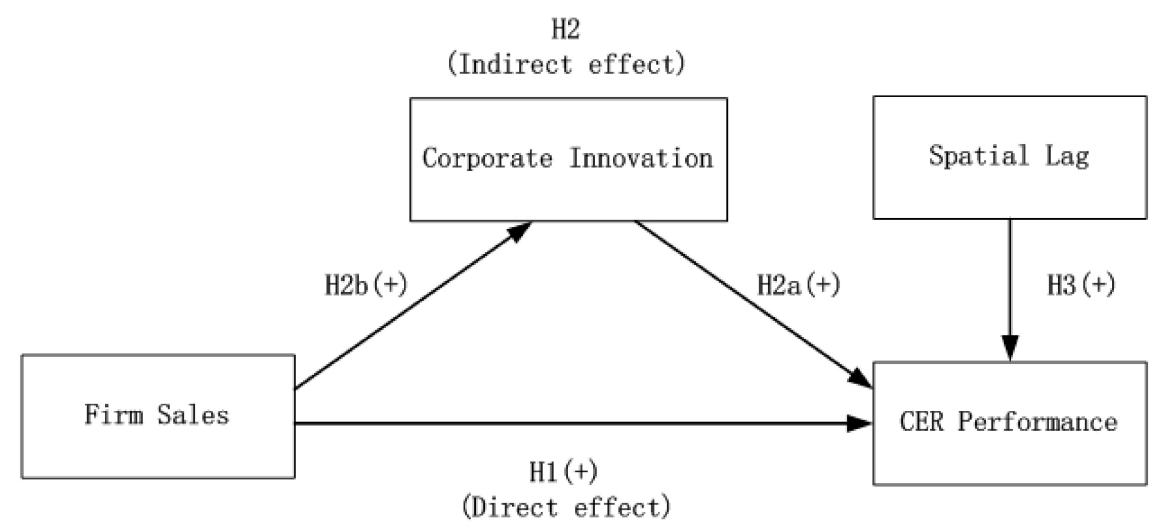

Figure 1. Theoretical model with hypotheses.

\section{Materials and Methods}

\subsection{Sample}

This study focused on Chinese companies that issued A-shares and went public before 31 December 2010, as the sample. Our study period was from 2010 to 2016. Delisted companies and companies with outliers in financial data were excluded. The number of companies after exclusions was 909. This study used companies' annual data from 2010 to 2016 and obtained 6363 data points from 909 companies. The 909 sample companies were listed companies with normal business operations and innovation capabilities during the study period. This included all CER-active firms in 2010. The company-level financial data were from the Wind database. CER and other CSR data were from Hexun.com's Social Responsibility Evaluation System. The macroeconomic data came from the provincial gross domestic product (GDP) growth rate taken from the Chinese National Bureau of Statistics website.

\subsection{Variable Measurement}

Explained variables: The study adopted the corporate environmental responsibility score (CERS) as a measure of CER performance. This metric is widely used in CER research [15,84]. In Hexun.com's Social Responsibility Evaluation System, CERS is a comprehensive score consisting of five aspects: environmental governance, environmental awareness, environmental management system certification, environmental protection investment amount, number of pollution types, and number of energy conservation types. The higher the CERS, the better the CER performance of the enterprise.

Explanatory variables: There are three explanatory variables. The first one is for sales. Here, the logarithm of sales revenue of listed companies (SALE) is used. The second one is the mediating variable: corporate innovation [28]. Patent output captures technology quality $[85,86]$. Therefore, it is sound to use patent output to measure corporate innovation. In China, there are invention and non-invention patents, including both utility model and design patents [87]. CER-related innovations are mainly concentrated on non-invention patents $[59,63]$. In the sample data, the annual non-invention patent volume of some sample companies is 0 . To ensure that the logarithm is meaningful even for variables with a value of 0 , the number of the non-invention patent is added with a small amount, such as 1 , before calculating the log value [88]. Thus, the logarithm for the number of non-invention patents (LNPs) plus one is used as the mediating variable.

The third one comprises the control variables. An important driving force of CER is the interest and pressure from suppliers, customers, and consumers [89]. Thus, suppliers, customers, and consumers' responsibilities (SCR) were used. Moreover, the control variables include the enterprise's age (AGE) and local GDP growth (GDP). Furthermore, the latitude and longitude data for the sample companies' addresses were collected to calculate spatial dynamics. The definitions of the relevant variables are summarized in Appendix A. 


\subsection{Descriptive Statistics}

Our research undertakes a preliminary disposition of the data described above and obtains 6363 observed values. The descriptive statistics are shown in Table 1.

Table 1. Descriptive statistics of variables.

\begin{tabular}{cccccc}
\hline Variable & Obs. & Mean & S.D. & Min. & Max. \\
\hline CERS & 6363 & 3.177 & 6.305 & 0 & 30 \\
SALE & 6363 & 3.302 & 1.475 & 0 & 10.268 \\
LNP & 6363 & 1.879 & 1.92 & 0 & 8.99 \\
SCR & 6363 & 3.168 & 5.965 & 0 & 20 \\
AGE & 6363 & 19.782 & 4.633 & 0 & 39 \\
GDP & 6363 & 9.444 & 2.665 & -2.5 & 17.4 \\
\hline
\end{tabular}

3.4. Methods

\subsubsection{Spatial Footprint Analysis}

Spatial footprint analysis is a descriptive analysis of the elliptical distribution of CER performance and its spatial dynamics. Lefever's standard deviation ellipse (SDE) method was adopted to measure the spatial footprint [90]. Next, the mean point of the SDE was calculated to measure the gravity center [91].

\subsubsection{Mediating Effect and Spatial Regression}

To test the hypotheses, a hierarchical regression, following the steps established by [92], was used. According to this methodology, first, a regression is performed to study the effect of the independent variable on the dependent variable. Second, the effect of the independent variable on the mediating variable is tested. Third, the effects of the independent and mediating variables on the dependent variable are tested in a single model. Moreover, because the dependent variable may have spatial autocorrelation, the spatial lagged value of the dependent variable is introduced into the model as an independent variable. Correspondingly, the models in our study proposed for testing the hypotheses are as follows:

$$
\begin{gathered}
C E R S=C+\rho_{1} W C E R S+\alpha_{1} S A L E+\beta_{1} S C R+\beta_{2} A G E+\beta_{3} G D P+\varepsilon \\
L N P=C+\rho_{2} W L N P+\beta S A L E+\beta_{1} S C R+\beta_{2} A G E+\beta_{3} A G D P+\varepsilon \\
C E R S=C+\rho W C E R S+\alpha_{2} S A L E+\gamma L N P+\beta_{1} S C R+\beta_{2} A G E+\beta_{3} G D P+\varepsilon
\end{gathered}
$$

here, $W$ is the spatial contiguity weight matrix. When two companies are adjacent, their weight is 1 ; if they are not adjacent, their weight is 0 .

\section{Results and Discussion}

\subsection{Spatial Footprint of CER and Its Evolution}

The SDE method is used to calculate the spatial ellipse of CERS, as shown in Figure 2. The dotted ellipse in Figure 2 is the spatial footprint of the CER performance in 2010, while the solid ellipse represents the same for 2016. The two small red dots in Figure 2 refer to the CER performance's center of gravity in 2010 and 2016. Comparing the shapes of both ellipses in Figure 2, it is obvious that the dashed ellipse is generally outside the solid ellipse. This shows that from 2010 to 2016, the spatial footprint of CER performance showed an outward expansion trend. That is, the CER performance of enterprises in core areas is getting better and better. This will have a positive spatial spillover effect and push peripheral companies to increase CER investment and improve CER performance. This phenomenon represents the spatial diffusion of CER [93]. This phenomenon can be also observed at a global level as companies cause a positive spatial spillover effect in improving CER performance $[76,77,80]$. There are many reasons for the spatial distribution of CER, one of which is that the R\&D activities related to CER have certain spatial distribution 
characteristics [94]. According to the change in the position of the center of gravity in Figure 2, from 2010 to 2016, the center of gravity of CER performance showed a trend of moving from east to west. This shows that the CER performance of Western companies is improving.

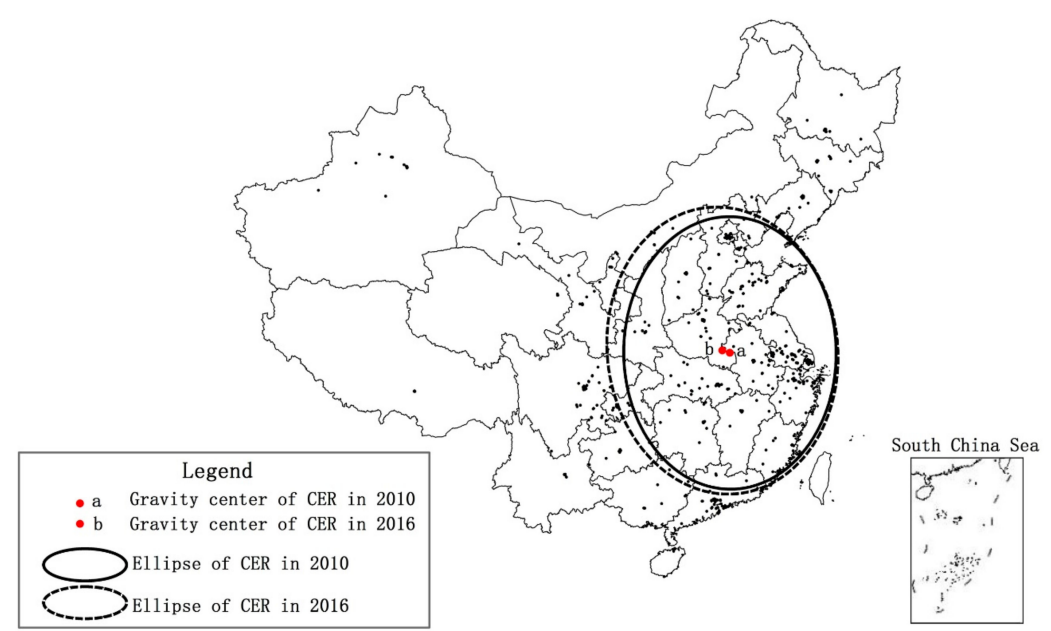

Figure 2. Spatial footprint of corporate environmental responsibility (CER) performance in 2010 and 2016.

Figure 3 shows the positions of the CER performance's center of gravity from 2010 to 2016. The center of gravity moves back and forth. This shows that listed companies in different regions have obvious strategic interactions in CER performance [12]. For example, in 2014, the Southwest region issued a policy to encourage CER investment. This led to an increase in CER investment by listed companies and caused the center of gravity to move southwest quickly. However, the Northeast region was aware of this change and introduced relevant policies in 2015. Listed companies in the Northeast region also adopted follow-up strategies and increased investment in CER, which resulted in a significant improvement in CER performance. As a result, the center of gravity moved quickly back to the Northeast in 2015. The displacement of the center of gravity reveals the spatial dynamics of the CER game [72,74]. According to the spatiotemporal context-strategic interaction-performance (SSP) model, this spatiotemporal context will affect the CER behavior of companies through strategic interactions between neighboring companies [83].

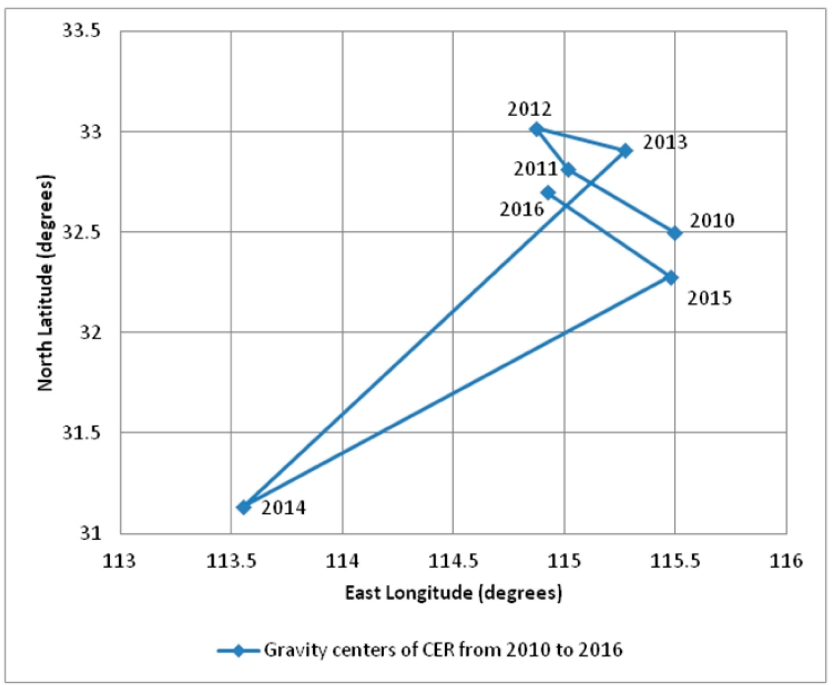

Figure 3. The spatial shifts in CER performance's center of gravity. 


\subsection{Estimation Results and Testing the Mediating Effect}

Spatial footprint analysis is still a univariate analysis. To further analyze the micromechanism of the CER game, a multivariate analysis was needed. According to Hypothesis 2 , the impact of sales on CER performance is mainly mediated through corporate innovation. Here, spatial lag regression models were used to test the mediating effect. The results are summarized in Table 2. Among them, Models 1, 2, and 3 correspond to Equations (1), (2), and (3), respectively. The Hausman test on the result of Model 3 showed that the result is not significant. Therefore, in the spatial lag panel regression model, the random effect model was used instead of the fixed-effects model. The regression results are summarized in Table 2.

Table 2. Results of estimation and mediating effect testing.

\begin{tabular}{|c|c|c|c|}
\hline & CERS & LNP & CERS \\
\hline & Model 1 & Model 2 & Model 3 \\
\hline SALE & $\begin{array}{c}0.232 * * * \\
(5.51)\end{array}$ & $\begin{array}{c}0.334^{* * *} \\
(18.49)\end{array}$ & $\begin{array}{c}0.205^{* * *} \\
(4.66)\end{array}$ \\
\hline LNP & & & $\begin{array}{c}0.066^{* *} \\
(2.02)\end{array}$ \\
\hline SCR & $\begin{array}{l}0.887 * * * \\
(123.67)\end{array}$ & $\begin{array}{l}0.005 \text { * } \\
(1.81)\end{array}$ & $\begin{array}{l}0.887 * * * \\
(123.56)\end{array}$ \\
\hline AGE & $\begin{array}{c}-0.057^{* * *} \\
(-3.73)\end{array}$ & $\begin{array}{c}0.038^{* * *} \\
(5.28)\end{array}$ & $\begin{array}{c}-0.058^{* * *} \\
(-3.82)\end{array}$ \\
\hline GDP & $\begin{array}{c}0.044^{* * *} \\
(2.64)\end{array}$ & $\begin{array}{c}-0.036^{* * *} \\
(-5.26)\end{array}$ & $\begin{array}{c}0.048^{* * *} \\
(2.85)\end{array}$ \\
\hline _cons & $\begin{array}{c}0.19 \\
(0.41)\end{array}$ & $\begin{array}{l}-0.227 \\
(-1.12)\end{array}$ & $\begin{array}{l}0.176 \\
(0.38)\end{array}$ \\
\hline$\rho$ & $\begin{array}{l}0.04^{* * *} \\
(2.93)\end{array}$ & $\begin{array}{l}0.112^{* * *} \\
(5.23)\end{array}$ & $\begin{array}{c}0.039 * * * \\
(2.89)\end{array}$ \\
\hline /sigma_u & 2.203 & 1.332 & 2.188 \\
\hline /sigma_e & 2.251 & 0.766 & 2.253 \\
\hline Log likelihood & $-15,120$ & -8746.14 & $-15,120$ \\
\hline Wald $\mathrm{chi}^{2}$ & $16,963.83^{* * *}$ & $954.41^{* * *}$ & $16,987.07^{* * *}$ \\
\hline Pseudo $\mathrm{R}^{2}$ & 0.75 & 0.189 & 0.752 \\
\hline Wald test of spatial terms & $8.58^{* * *}$ & $27.35^{* * *}$ & $8.36^{* * *}$ \\
\hline
\end{tabular}

Note: ${ }^{*}{ }^{* *}$, and ${ }^{* * *}$ are significant at $0.1,0.05$, and 0.01 , respectively.

According to Models 1 and 3, the regression coefficients of SALE ( $\alpha_{1}$ in formula (1) and $\alpha_{2}$ in formula (2)) are both positive and significant. This shows that sales positively impact CER performance. The higher the company's sales, the better the company's CER performance $[35,38]$. This is consistent with previous research $[39,41]$. Therefore, Hypothesis 1 is supported. Hence, sales revenue is an important and basic factor driving CER performance.

The regression coefficient of LNP $(\gamma)$ in Model 3 is positive and significant. This shows that there is a positive correlation between corporate innovation and CER performance, which is consistent with previous research conclusions $[20,51,55]$. Therefore, Hypothesis $2 \mathrm{a}$ is supported. Further, the regression coefficient of SALE ( $\beta)$ in Model 2 is positive and significant. This shows that the level of corporate innovation increases as sales increase, which is again in line with previous research $[57,58,61]$. Thus, the results in Table 2 show that corporate innovation mediates the relationship between sales and CER performance. Therefore, Hypothesis 2 is supported.

In the three models listed in Table 3 , the coefficients $\rho$ are all positive and significant. This shows that there is a positive spatial spillover effect on the CER performance of neighboring companies [72]. In the CER game, each company will not act independently; they will incorporate, to some extent, the behavior of their neighboring competitors [67]. There are at least three channels through which enterprises are expected to affect the CER 
performance of their neighboring competitors. First, CER expenditure competition will occur when enterprises compete with their neighbors to attract local social support and resources, thereby inducing a joint increase in CER investment by neighboring companies [65]. Second, yardstick competition in the CER game will occur when enterprises ${ }^{\prime}$ spending on CER promotes sales performance, thereby driving improvements in the CER performance of neighboring companies [66]. Third, CER expenditure externalities will occur when environmental protection spending by one or more enterprises has detrimental effects on their neighboring enterprises [71,74]. There should be positive spatial spillovers in the performance of neighboring companies. Thus, Hypothesis 3 is supported.

Table 3. Results of estimation and mediating effect testing in difference models.

\begin{tabular}{|c|c|c|c|}
\hline & CSRH & PAT & CSRH \\
\hline & Model 3 & Model 5 & Model 6 \\
\hline SALE & $\begin{array}{c}0.207^{* * *} \\
(2.39)\end{array}$ & $\begin{array}{c}0.199^{* * *} \\
(6.98)\end{array}$ & $\begin{array}{l}0.19 * * \\
(2.19)\end{array}$ \\
\hline PAT & & & $\begin{array}{c}0.086^{* *} \\
(2.09)\end{array}$ \\
\hline CSRT & $\begin{array}{l}0.857^{* * *} \\
(111.05)\end{array}$ & $\begin{array}{c}0.005 * \\
(1.81)\end{array}$ & $\begin{array}{l}0.857 * * * \\
(111.04)\end{array}$ \\
\hline AGE & $\begin{array}{l}-0.065 \\
(-1.26)\end{array}$ & $\begin{array}{c}0.121^{* * *} \\
(7.1)\end{array}$ & $\begin{array}{l}-0.075 \\
(-1.46)\end{array}$ \\
\hline GDP & $\begin{array}{l}0.025 \\
(0.71)\end{array}$ & $\begin{array}{l}-0.016 \\
(-1.37)\end{array}$ & $\begin{array}{l}0.027 \\
(0.77)\end{array}$ \\
\hline$\rho$ & $\begin{array}{c}0.046^{* * *} \\
(3.13)\end{array}$ & $\begin{array}{c}0.051^{* *} \\
(2.06)\end{array}$ & $\begin{array}{c}0.045^{* * *} \\
(3.05)\end{array}$ \\
\hline /sigma_u & 1.49 & 5.01 & -2.68 \\
\hline /sigma_e & 2.817 & 0.927 & 2.816 \\
\hline Log likelihood & $-15,120$ & -7327.17 & $-13,390$ \\
\hline Wald chi ${ }^{2}$ & $13,093.84^{* * *}$ & $228.06^{* * *}$ & $13,108.43^{* * *}$ \\
\hline Pseudo $\mathrm{R}^{2}$ & 0.706 & 0.101 & 0.706 \\
\hline Wald test of spatial terms & $9.82 * * *$ & $4.22^{* *}$ & $9.27^{* * *}$ \\
\hline
\end{tabular}

In terms of firm-level factors, if the SCR performance is higher, then the CER performance is higher. The pressure from suppliers, customers, and consumers on environmental protection is often the direct motive for companies to improve CER performance [89]. There is a negative relationship between CER performance and the age of an enterprise (AGE). This may be related to the so-called corporate inertia [95]. Further, there is a positive relationship between CER performance and local GDP growth (GDP). The faster the economy develops, the higher the environmental protection requirements for local companies, and the better the CER performance [96].

\subsection{Endogeneity Issues}

The relationship between firm sales and CER performance may have reverse causality, that is, the endogenous problem of missing variables. To control for the endogenous problem, the difference variables can be obtained by calculating the difference between the current period and the previous period of the relevant variables. Then, these difference variables are used to run the spatial lag panel model regression with random effects. The time span of the difference model is from 2011 to 2016, and the number of observation points is 5454. The regression results are summarized in Table 3 and are qualitatively similar to the results in Table 2.

The hysteresis phenomenon has received renewed attention in economic and business science $[97,98]$. When the market sales are transmitted to the enterprise through a certain mechanism and have an impact on CER, there often is a time gap. Therefore, there will be hysteresis. In order to test whether this hysteresis phenomenon exists, the sales of the 
previous period and the $\mathrm{t}-2$ period are used as independent variables in regression models, respectively. In Model 7, Model 8, and Model 9, the sales revenue of the previous period is used as the independent variable. The study time is from 2011 to 2016, with a total of 5454 observations. In Model 10, Model 11, and Model 12, the sales revenue of the t-2 period is used as the independent variable. The study time is from 2012 to 2016, with a total of 4545 observations. The results are summarized in Table 4.

Table 4. Results of estimation and mediating effect testing with sales of lag periods.

\begin{tabular}{|c|c|c|c|c|c|c|}
\hline & CERS & LNP & CERS & CERS & LNP & CERS \\
\hline & Model 7 & Model 8 & Model 9 & Model 10 & Model 11 & Model 12 \\
\hline$S A L E_{t-1}$ & $\begin{array}{c}0.161^{* * * *} \\
(3.64)\end{array}$ & $\begin{array}{c}0.316^{* * *} \\
(15.15)\end{array}$ & $\begin{array}{c}0.114^{* *} \\
(2.46)\end{array}$ & & & \\
\hline$S A L E_{t-2}$ & & & & $\begin{array}{c}0.148^{* * *} \\
(3.23)\end{array}$ & $\begin{array}{c}0.332^{* * *} \\
(13.12)\end{array}$ & $\begin{array}{l}0.09 * \\
(1.87)\end{array}$ \\
\hline LNP & & & $\begin{array}{l}0.112^{* *} \\
(3.31)\end{array}$ & & & $\begin{array}{c}0.135^{* * *} \\
(3.86)\end{array}$ \\
\hline SCR & $\begin{array}{c}0.892 * * * \\
(120.8)\end{array}$ & $\begin{array}{l}0.005 * \\
(1.94)\end{array}$ & $\begin{array}{l}0.892^{* * *} \\
(120.67)\end{array}$ & $\begin{array}{c}0.882 \text { *** } \\
(116.1)\end{array}$ & $\begin{array}{c}0.006^{* *} \\
(2.09)\end{array}$ & $\begin{array}{l}0.881^{* * *} \\
(115.97)\end{array}$ \\
\hline AGE & $\begin{array}{c}-0.052^{* * *} \\
(-3.43)\end{array}$ & $\begin{array}{c}0.029 * * * \\
(3.85)\end{array}$ & $\begin{array}{c}-0.053^{* * *} \\
(-3.5)\end{array}$ & $\begin{array}{c}-0.037^{* *} \\
(-2.35)\end{array}$ & $\begin{array}{c}0.027^{* * *} \\
(3.2)\end{array}$ & $\begin{array}{c}-0.037^{* *} \\
(-2.4)\end{array}$ \\
\hline GDP & $\begin{array}{c}0.059^{* * *} \\
(3.04)\end{array}$ & $\begin{array}{c}-0.018^{* *} \\
(-2.37)\end{array}$ & $\begin{array}{c}0.063^{* * *} \\
(3.23)\end{array}$ & $\begin{array}{c}0.103^{* * *} \\
(4.46)\end{array}$ & $\begin{array}{c}-0.023^{* *} \\
(-2.5)\end{array}$ & $\begin{array}{c}0.107^{* * *} \\
(4.67)\end{array}$ \\
\hline _cons & $\begin{array}{l}0.213 \\
(0.46)\end{array}$ & $\begin{array}{l}-0.048 \\
(-0.22)\end{array}$ & $\begin{array}{c}0.183 \\
(0.4)\end{array}$ & $\begin{array}{l}-0.373 \\
(-0.77)\end{array}$ & $\begin{array}{l}0.066 \\
(0.27)\end{array}$ & $\begin{array}{c}-0.42 \\
(-0.88)\end{array}$ \\
\hline$\rho$ & $\begin{array}{c}0.04^{* * *} \\
(2.81)\end{array}$ & $\begin{array}{c}0.086 * * * \\
(3.65)\end{array}$ & $\begin{array}{c}0.039 * * * \\
(2.79)\end{array}$ & $\begin{array}{c}0.035 * * \\
(2.37)\end{array}$ & $\begin{array}{c}0.092^{* * *} \\
(3.59)\end{array}$ & $\begin{array}{c}0.034^{* *} \\
(2.32)\end{array}$ \\
\hline /sigma_u & 2.091 & 1.392 & 2.07 & 2.027 & 1.42 & 2.003 \\
\hline /sigma_e & 2.217 & 0.752 & 2.218 & 2.144 & 0.741 & 2.144 \\
\hline Log likelihood & $-12,920$ & -7583.37 & $-12,920$ & $-10,690$ & -5436.42 & $-10,680$ \\
\hline Wald chi ${ }^{2}$ & $16,275.58 * * *$ & $417.92 * * *$ & $16,329.21^{* * *}$ & $15,005.12^{* * *}$ & $297.61 * * *$ & $15,075.17^{* * *}$ \\
\hline Pseudo $\mathrm{R}^{2}$ & 0.765 & 0.189 & 0.767 & 0.772 & 0.186 & 0.775 \\
\hline Wald test of spatial terms & $7.92 * * *$ & $13.3^{* * *}$ & $7.77^{* * *}$ & $5.61 * * *$ & $12.86^{* * *}$ & $5.4^{* *}$ \\
\hline
\end{tabular}

Note: ${ }^{*}, * *$ and ${ }^{* * *}$ are significant at $0.1,0.05$, and 0.01 , respectively.

Comparing Tables 2 and 4 , it is obvious that the results of Table 4 basically replicate the results of Table 2 . It shows that the main conclusions of this study are robust. The results in Table 4 show that there is a lagging effect of the impact of sales on corporate CER. The sales of the previous period and the $t-2$ period are positive with CER. This hysteresis effect is mainly caused by three factors: psychological factor, technical factor, and institutional factor. Psychologically, due to psychological stereotypes, people's behavior patterns lag behind the changes in market conditions. Technically, the technological innovation output of the year relied on R\&D input in the past several periods. Institutionally, major corporate decisions often need to be negotiated through high-level formal meetings, resulting in a lagging response to the market.

Comparing Model 3 in Table 2 with Model 9 and Model 12 in Table 4, it is shown that the regression coefficient of sales has changed from 0.205 in Model 3 to 0.114 in Model 9 and 0.09 in Model 12. In other words, this shows a decreasing trend. It means that although sales revenue has a long-term impact on CER, as the lag period increases, this impact will weaken. The impact of sales on CER shows time decay characteristics. In addition, the regression coefficients of the spatial lag term $(\rho)$ of all models in Tables 2 and 4 are positive and significant. This shows that there is a positive spillover effect on CER between neighboring companies. Those results further confirm the influence of external factors on corporate CER. This study identified the two main external stakeholders that affect the corporate CER: consumers and neighboring competitors. The external control theory of organization proposed by Pfeffer and Salancik [21] has important reference significance 
and explanatory power for CER behavior in emerging economies, both in theory and in practice.

\subsection{Robustness Test}

Six rounds of mediating effect testing were implemented to investigate the relationship between sales and CER performance. The regression results are summarized in Table 5. In round one of Table 5, the mediating variable, the number of non-inventory patents, is replaced by the total number of patents. In rounds two, three, and four, the five year periods from 2010 to 2014, 2011 to 2015, and 2012 to 2016 are chosen as the research period, respectively. In round five, the spatial inverse-distance weight is used. In round six, the spatial inverse-distance contiguity weight is used. $\alpha_{1}, \alpha_{2}, \beta, \lambda$, and $\rho$ are the regression coefficients in Equations (1)-(3). The results in Table 5 are qualitatively similar to the results in Table 2. This shows that even if different innovation measurement indicators are used in different periods with different spatial weight matrices, the main conclusions of this study are still valid.

Table 5. Six rounds of mediating effect testing.

\begin{tabular}{ccccccc}
\hline & $\alpha_{1}$ & $\beta$ & $\lambda$ & $\alpha_{2}$ & $\rho$ & Pseudo R $^{2}$ \\
\hline Round one & $0.232^{* * *}$ & $0.375^{* * *}$ & $0.069^{* * *}$ & $0.199^{* * *}$ & $0.039^{* * *}$ & 0.752 \\
\hline Round two & $0.307^{* * *}$ & $0.362^{* * *}$ & $0.155^{* *}$ & $0.243^{* * *}$ & $0.041^{* * *}$ & 0.746 \\
\hline Round three & $0.222^{* * *}$ & $0.371^{* * *}$ & $0.147^{* *}$ & $0.154^{* * *}$ & $0.041^{* * *}$ & 0.771 \\
\hline Round four & $0.187^{* * *}$ & $0.381^{* * *}$ & $0.122^{* * *}$ & $0.13^{* * *}$ & $0.034^{* *}$ & 0.775 \\
\hline Round five & $0.23^{* * *}$ & $0.338^{* * *}$ & $0.068^{* *}$ & $0.203^{* * *}$ & $0.114^{* *}$ & 0.753 \\
\hline Round six & $0.233^{* * *}$ & $0.337^{* * *}$ & $0.069^{* *}$ & $0.205^{* * *}$ & $0.105^{* * *}$ & 0.753 \\
\hline
\end{tabular}

Note. $^{* *}$ and ${ }^{* * *}$ denote significance at the 0.05 and 0.01 levels, respectively. Further details on each model are contained in Appendix B. All variables are defined in Appendix A.

\section{Discussion}

In the past, most studies on CER analyzed the impact of CER on business performance $[5,6]$. The main conclusion is that the implementation of environmental responsibility activities by companies can help promote corporate sales and improve corporate performance. This traditional analysis logic is from inside of firms to outside of firms. CER is transferred to the market value through a certain mechanism, thereby affecting the market sales of corporate products or services $[25,28]$. However, in reality, external factors such as consumers' preference for environmental responsibility and market competition pressure push companies to improve their CER performance [89]. This analysis logic is from the outside of firms to the inside of firms, and this logic is more in line with objective reality. For example, $54 \%$ of the research subjects said they would buy the company's new product or brand because of the company's charity [99]. Consumers would like to buy products from companies with CER performance and use them as an external manifestation of their lifestyle and moral standards [100]. This kind of consumer demand has exerted external market pressure on enterprises. If the company cannot effectively meet the needs of consumers, then consumers will "vote with feet" and stop buying products from companies that perform poorly in CER, and the sales performance will decline. Therefore, CER is a response for firms to consumer demand. This study found that the current sales performance of a company has a positive impact on CER performance. This confirms the influence of the market on CER behavior [36-38].

In this process of influencing from outside to inside, corporate innovation plays an important intermediary role. In the past, corporate innovation generally emphasized technological innovation, and the role of innovation in CER was often overlooked. When consumers are willing to pay higher prices for products of companies that perform well in CER, this signal will be transmitted to the company in time, and the company will adjust innovation strategies in time to produce environmentally friendly, energy-saving, and 
high-quality products through innovation [28]. For example, empirical research results show that companies will improve their CER performance through green innovation, and the sales and operating performance of such companies are often better [101]. Therefore, innovation plays an important role as a "translator" between the market and CER behaviors. On the one hand, it allows companies to implement environmental responsibility actions innovatively; on the other hand, a company's strong innovation ability will itself deliver positive energy to the market, which is itself a part of CER.

Effectively responding to consumers' demands via innovation to improve CER performance is actually an important way for companies to build core competitiveness. The practice of enterprises to improve their CER performance through innovation will also produce obvious positive spatial spillover effects [76,77]. This spatial spillover effect is mainly reflected in two aspects. On the one hand, if a company has achieved good performance in environmental responsibility, it will generate a good reputation and reputation in the market. Neighboring companies will learn and imitate to increase investment in CER and improve their performance of CER. On the other hand, the practice of companies using technological innovation to improve their CER performance is easy to be noticed by neighboring companies, leading neighboring companies to follow suit. For example, green innovation often has positive spatial spillover effects [101]. The spatial spillover of technological innovation is also one of the important ways to strengthen the spillover effect of CER.

\subsection{Theoretical Implications}

Many scholars conduct CER research from the internal perspective of the enterprise and focus on the impact of CER behavior on market sales performance. In fact, in the real world, consumers' purchase intentions and purchase behaviors play a decisive role in the performance of a company and are also the goal pursued by the company in production and operation. Therefore, from the external perspective of the enterprise, the CER behavior of firms is best understood. This research analyzed the impact of sales revenue on CER performance and found a positive relationship between them. In addition, this study also found that corporate innovation plays an important intermediary role between sales revenue and CER. In terms of environmental responsibility, neighboring companies often imitate each other, that is, there is a spatial spillover effect. These research results confirm the external control theory of organization, expanding the field and scope of CER research effectively.

\subsection{Managerial and Policy Implications}

The conclusions of this study have important management and policy significance. In terms of management, enterprises cannot simply regard innovation as a technological update but must be closely integrated with CER. Enterprises use technological innovation to improve production processes, develop new products, process innovations, or management innovations to meet the needs of consumers, shareholders, and other stakeholders in order to fulfill their environmental responsibilities. This will help enhance corporate social reputation, improve corporate performance, enhance corporate competitiveness, and help promote the transformation of economic development mode and industrial transformation and upgrading. In terms of policy, the government needs to speed up the improvement of the corporate environmental responsibility disclosure mechanism and the establishment of a legal system related to CER, focusing on the role of the market, reducing market information asymmetry, guiding enterprises to actively perform social responsibilities. Environmental responsibility incentive policies such as innovative tax relief and government subsidy policies should be issued to encourage enterprise innovation and optimize enterprise resource allocation. In this way, a virtuous circle and mutual promotion of CER, corporate innovation, and market performance are formed. 


\section{Conclusions}

In this study, whether a company's sales affect its corporate environmental responsibility (CER) performance was examined. The empirical results of 909 listed companies in China show that sales affect CER performance and that corporate innovation is a mediator variable between sales and CER performance. This study has implications for CER practices. Local governments can encourage enterprises to increase CER investment and improve CER performance by outlining CER success stories and conducting reasonable publicity. Enterprises should strengthen market-oriented innovation activities, improve innovation capabilities, and increase the output of CER inputs through innovation. This can foster a conversion effect between market sales and CER investment, and thereby, form a virtuous circle that can effectively achieve a balance between environmental protection and commercial benefits.

Funding: The author discloses receipt of the following financial support for the research, authorship, and/or publication of this article: this research was funded by the National Social Science Foundation of China (17BSH122).

Data Availability Statement: Not applicable.

Acknowledgments: The author gratefully acknowledges the Social Science Foundation of China (17BSH122) for the support of this research. I would like to express my thanks to Lorenzo Ardito, the editor, and two anonymous reviewers for their insightful comments and suggestions.

Conflicts of Interest: The author(s) declare no potential conflict of interest with respect to the research, authorship, and/or publication of this article.

Appendix A. Variable Symbols and Definitions

\begin{tabular}{cc}
\hline Variable Abbreviation & Variable Definition \\
\hline CERS & CER score, the Hexun.com Social Responsibility Evaluation System \\
SALE & the logarithm for the sales revenue of listed companies (unit: CNY 100 million) \\
LNP & logarithmic value after adding 1 to the total N for non-invention patent \\
SCR & suppliers, customers, and consumers' responsibilities \\
AGE & age: years the company has been listed (the difference between founding year and current year +1) \\
GDP & GDP growth rate, by province \\
\hline
\end{tabular}

Appendix B. Additional Tests for Robustness Check

${ }^{*}, * *$, and ${ }^{* *}$ are significant at $0.1,0.05$, and 0.01 , respectively.

\begin{tabular}{|c|c|c|c|}
\hline & \multicolumn{3}{|c|}{ Round One: Total Patents as the Mediating Variable } \\
\hline & CSRH & PAT & CSRH \\
\hline & Model 1 & Model 2 & Model 3 \\
\hline SALE & $\begin{array}{c}0.232 \text { *** } \\
(5.51)\end{array}$ & $\begin{array}{c}0.375^{* * *} \\
(19.96)\end{array}$ & $\begin{array}{c}0.199 * * * \\
(4.47)\end{array}$ \\
\hline PAT & & & $\begin{array}{c}0.069 * * \\
(2.22)\end{array}$ \\
\hline CSRT & $\begin{array}{l}0.887^{* * *} \\
(123.67)\end{array}$ & $\begin{array}{l}0.004 \\
(1.54)\end{array}$ & $\begin{array}{l}0.887^{* * *} \\
(123.52)\end{array}$ \\
\hline AGE & $\begin{array}{c}-0.057^{* * *} \\
(-3.73)\end{array}$ & $\begin{array}{c}0.047^{* * *} \\
(6.08)\end{array}$ & $\begin{array}{c}-0.058^{* * *} \\
(-3.81)\end{array}$ \\
\hline GDP & $\begin{array}{c}0.044^{* * *} \\
(2.64)\end{array}$ & $\begin{array}{c}-0.022 * * * \\
(-3.12)\end{array}$ & $\begin{array}{c}0.048^{* * *} \\
(2.83)\end{array}$ \\
\hline _cons & $\begin{array}{c}0.19 \\
(0.41)\end{array}$ & $\begin{array}{l}-0.245 \\
(-1.14)\end{array}$ & $\begin{array}{l}0.161 \\
(0.35)\end{array}$ \\
\hline$\rho$ & $\begin{array}{c}0.04^{* * *} \\
(2.93)\end{array}$ & $\begin{array}{c}0.094^{* * *} \\
(4.36)\end{array}$ & $\begin{array}{c}0.039 * * * \\
(2.92)\end{array}$ \\
\hline /sigma_u & 2.203 & 1.548 & 2.187 \\
\hline /sigma_e & 2.251 & 0.769 & 2.253 \\
\hline Log likelihood & $-15,120$ & -8894.1 & $-15,120$ \\
\hline Wald chi2 & $16,963.83^{* * *}$ & $952.06^{* * *}$ & $16,990.92^{* * *}$ \\
\hline Pseudo R2 & 0.75 & 0.193 & 0.752 \\
\hline Wald test of spatial terms & $8.58 * * *$ & $19^{* * *}$ & $8.5 * * *$ \\
\hline
\end{tabular}




\begin{tabular}{|c|c|c|c|c|c|c|c|c|c|}
\hline & \multicolumn{3}{|c|}{ Round Two: 2010-2014 } & \multicolumn{3}{|c|}{ Round Three: 2011-2015 } & \multicolumn{3}{|c|}{ Round Four: 2012-2016 } \\
\hline & CSRH & PAT & CSRH & CSRH & PAT & CSRH & CSRH & PAT & CSRH \\
\hline & Model 1 & Model 2 & Model 3 & Model 1 & Model 2 & Model 3 & Model 1 & Model 2 & Model 3 \\
\hline SALE & $\begin{array}{c}0.307^{* * *} \\
(5.98)\end{array}$ & $\begin{array}{c}0.362 * * * \\
(16.96)\end{array}$ & $\begin{array}{c}0.243^{* * *} \\
(4.49)\end{array}$ & $\begin{array}{c}0.222^{* * *} \\
(4.73)\end{array}$ & $\begin{array}{c}0.371^{* * *} \\
(16.66)\end{array}$ & $\begin{array}{c}0.154^{* * *} \\
(3.1)\end{array}$ & $\begin{array}{c}0.187^{* * *} \\
(4.16)\end{array}$ & $\begin{array}{c}0.381^{* * *} \\
(17.23)\end{array}$ & $\begin{array}{c}0.13^{* * *} \\
(2.73)\end{array}$ \\
\hline PAT & & & $\begin{array}{c}0.155^{* *} \\
(3.79)\end{array}$ & & & $\begin{array}{c}0.147^{* *} \\
(3.95)\end{array}$ & & & $\begin{array}{c}0.122 \text { *** } \\
(3.45)\end{array}$ \\
\hline CSRT & $\begin{array}{c}0.891 * * * \\
(97.44)\end{array}$ & $\begin{array}{l}0.005 * \\
(1.76)\end{array}$ & $\begin{array}{l}0.89 * * * \\
(97.35)\end{array}$ & $\begin{array}{l}0.908^{* * *} \\
(110.83)\end{array}$ & $\begin{array}{l}0.001 \\
(0.46)\end{array}$ & $\begin{array}{l}0.907^{* * *} \\
(110.79)\end{array}$ & $\begin{array}{l}0.881^{* * *} \\
(116.01)\end{array}$ & $\begin{array}{l}0.005 * \\
(1.66)\end{array}$ & $\begin{array}{l}0.88^{* * *} \\
(115.9)\end{array}$ \\
\hline AGE & $\begin{array}{c}-0.067^{* * *} \\
(-3.54)\end{array}$ & $\begin{array}{c}0.015^{* *} \\
(1.76)\end{array}$ & $\begin{array}{c}-0.068^{* * *} \\
(-3.6)\end{array}$ & $\begin{array}{c}-0.052^{* * * *} \\
(-3.08)\end{array}$ & $\begin{array}{l}0.006 \\
(0.75)\end{array}$ & $\begin{array}{c}-0.051 \text { *** } \\
(-3.05)\end{array}$ & $\begin{array}{c}-0.037^{* * * *} \\
(-2.35)\end{array}$ & $\begin{array}{c}0.026^{* * *} \\
(3.22)\end{array}$ & $\begin{array}{c}-0.037^{* * *} \\
(-2.39)\end{array}$ \\
\hline GDP & $\begin{array}{c}0.048^{* *} \\
(2.21)\end{array}$ & $\begin{array}{c}-0.054^{* * *} \\
(-6.57)\end{array}$ & $\begin{array}{c}0.058^{* * *} \\
(2.67)\end{array}$ & $\begin{array}{c}0.055^{* *} \\
(2.48)\end{array}$ & $\begin{array}{c}-0.019 * * \\
(-2.24)\end{array}$ & $\begin{array}{c}0.058^{* * *} \\
(2.65)\end{array}$ & $\begin{array}{c}0.105^{* * *} \\
(4.57)\end{array}$ & $\begin{array}{c}-0.021 * * * \\
(-2.27)\end{array}$ & $\begin{array}{c}0.109^{* * *} \\
(4.75)\end{array}$ \\
\hline _cons & $\begin{array}{l}0.081 \\
(0.14)\end{array}$ & $\begin{array}{l}0.307 \\
(1.24)\end{array}$ & $\begin{array}{l}0.001 \\
(0.01)\end{array}$ & $\begin{array}{l}-0.026 \\
(-0.05)\end{array}$ & $\begin{array}{l}0.191 \\
(0.76)\end{array}$ & $\begin{array}{l}-0.069 \\
(-0.14)\end{array}$ & $\begin{array}{l}-0.545 \\
(-1.13)\end{array}$ & $\begin{array}{l}-0.237 \\
(-1.01)\end{array}$ & $\begin{array}{l}-0.565 \\
(-1.18)\end{array}$ \\
\hline$\rho$ & $\begin{array}{c}0.02 * * * \\
(2.59)\end{array}$ & $\begin{array}{c}0.092^{* * *} \\
(3.67)\end{array}$ & $\begin{array}{c}0.041^{* * *} \\
(2.52)\end{array}$ & $\begin{array}{c}0.04^{* * *} \\
(2.62)\end{array}$ & $\begin{array}{c}0.073^{* * *} \\
(2.76)\end{array}$ & $\begin{array}{c}0.041^{* * *} \\
(2.65)\end{array}$ & $\begin{array}{c}0.034^{* *} \\
(2.32)\end{array}$ & $\begin{array}{c}0.09 * * * \\
(3.53)\end{array}$ & $\begin{array}{c}0.034^{* *} \\
(2.3)\end{array}$ \\
\hline /sigma_e & 2.222 & 0.697 & 2.224 & 2.201 & 0.701 & 2.202 & 2.14 & 0.732 & 2.142 \\
\hline Obs & 4545 & 4545 & 4545 & 4545 & 4545 & 4545 & 4545 & 4545 & 4545 \\
\hline Log likelihood & $-10,950$ & -6134.42 & $-10,940$ & $-10,800$ & -6202.81 & $-10,790$ & $-10,580$ & -6378.34 & $-10,680$ \\
\hline Wald chi2 & $11,023.1^{* * *}$ & $616.72 * * *$ & $11,090.24^{* * *}$ & $14,186.3^{* * *}$ & $340.78^{* * *}$ & $14,255.67^{* * *}$ & $15,035.73^{* * *}$ & $425.56^{* * *}$ & $165,091.8^{* * *}$ \\
\hline Pseudo R2 & 0.743 & 0.207 & 0.746 & 0.768 & 0.204 & 0.771 & 0.772 & 0.193 & 0.775 \\
\hline Wald test of spatial terms & $6.7^{* * *}$ & $13.47^{* * *}$ & $6.36^{* * *}$ & $6.84^{* * *}$ & $7.79 * * *$ & $7.04^{* * *}$ & $5.4^{* * *}$ & $12.48^{* * *}$ & $5.29 * * *$ \\
\hline
\end{tabular}




\begin{tabular}{|c|c|c|c|c|c|c|}
\hline & \multicolumn{3}{|c|}{ Round Five: Spatial Inverse-Distance Weight } & \multicolumn{3}{|c|}{ Round Six: Spatial Inverse-Distance Contiguity Weight } \\
\hline & CSRH & PAT & CSRH & CSRH & PAT & CSRH \\
\hline & Model 1 & Model 2 & Model 3 & Model 1 & Model 2 & Model 3 \\
\hline SALE & $\begin{array}{l}0.23 \text { *** } \\
(5.47)\end{array}$ & $\begin{array}{c}0.338^{* * *} \\
(18.58)\end{array}$ & $\begin{array}{c}0.203^{* * *} \\
(4.6)\end{array}$ & $\begin{array}{c}0.233^{* * * *} \\
(5.54)\end{array}$ & $\begin{array}{c}0.337^{* * * *} \\
(18.56)\end{array}$ & $\begin{array}{c}0.205^{* * *} \\
(4.66)\end{array}$ \\
\hline PAT & & & $\begin{array}{c}0.068^{* *} \\
(2.07)\end{array}$ & & & $\begin{array}{c}0.069 \text { ** } \\
(2.09)\end{array}$ \\
\hline CSRT & $\begin{array}{l}0.895^{* * *} \\
(124.65)\end{array}$ & $\begin{array}{l}0.005^{*} \\
(1.96)\end{array}$ & $\begin{array}{c}0.894^{* * *} \\
(124.5)\end{array}$ & $\begin{array}{l}0.893 * * * \\
(125.66)\end{array}$ & $\begin{array}{c}0.005^{*} \\
(1.96)\end{array}$ & $\begin{array}{l}0.893 * * * \\
(125.52)\end{array}$ \\
\hline AGE & $\begin{array}{c}-0.063^{* * *} \\
(-4.13)\end{array}$ & $\begin{array}{c}0.046^{* * *} \\
(6.28)\end{array}$ & $\begin{array}{c}-0.064^{* * *} \\
(-4.22)\end{array}$ & $\begin{array}{c}-0.061^{* * *} \\
(-3.99)\end{array}$ & $\begin{array}{c}0.045^{* * * *} \\
(6.25)\end{array}$ & $\begin{array}{c}-0.062 * * * \\
(-4.08)\end{array}$ \\
\hline GDP & $\begin{array}{c}0.051 * * * \\
(3.02)\end{array}$ & $\begin{array}{c}-0.04^{* * *} \\
(-5.99)\end{array}$ & $\begin{array}{c}0.054^{* * *} \\
(3.23)\end{array}$ & $\begin{array}{c}0.051 \text { *** } \\
(3.05)\end{array}$ & $\begin{array}{c}-0.04 * * * \\
(-5.96)\end{array}$ & $\begin{array}{c}0.055^{* * *} \\
(3.26)\end{array}$ \\
\hline _cons & $\begin{array}{l}0.433 \\
(0.94)\end{array}$ & $\begin{array}{l}-0.178 \\
(-0.87)\end{array}$ & $\begin{array}{l}0.415 \\
(0.91)\end{array}$ & $\begin{array}{l}0.339 \\
(0.74)\end{array}$ & $\begin{array}{l}-0.177 \\
(-0.87)\end{array}$ & $\begin{array}{l}0.322 \\
(0.71)\end{array}$ \\
\hline$\rho$ & $\begin{array}{c}0.114^{* *} \\
(2.5)\end{array}$ & $\begin{array}{l}0.098 \\
(1.21)\end{array}$ & $\begin{array}{c}0.114^{* *} \\
(2.5)\end{array}$ & $\begin{array}{c}0.104^{* * *} \\
(2.61)\end{array}$ & $\begin{array}{l}0.061 \\
(0.99) \\
\end{array}$ & $\begin{array}{c}0.105^{* * *} \\
(2.62)\end{array}$ \\
\hline /sigma_u & 2.193 & 1.345 & 2.179 & 2.193 & 1.346 & 2.178 \\
\hline /sigma_e & 2.254 & 0.767 & 2.255 & 2.253 & 0.767 & 2.254 \\
\hline Log likelihood & $-15,120$ & -8758.86 & $-15,120$ & $-15,120$ & -8759.1 & $-15,120$ \\
\hline Wald chi2 & $16,959.13^{* * *}$ & $923.96^{* * *}$ & $16,982.83^{* * *}$ & $16,963.5^{* * *}$ & $923.49^{* * *}$ & $16,987.91 * * *$ \\
\hline Pseudo R2 & 0.751 & 0.186 & 0.753 & 0.751 & 0.185 & 0.753 \\
\hline Wald test of spatial terms & $6.27^{* *}$ & 1.47 & $6.23 * *$ & $6.82 * * *$ & 0.98 & $6.88^{* * *}$ \\
\hline
\end{tabular}

\section{References}

1. Hosein, R.; Singh, T.; Conrad, D. CSR as a hartwick rule strategy to mitigate the impact of the resource curse: Lessons for the educational sector in Guyana from Trinidad and Tobago and Suriname. Soc. Econ. Stud. 2018, 67, 149-175.

2. Borger, F.G.; Kruglianskas, I. Corporate social responsibility and environmental and technological innovation performance: Case studies of Brazilian companies. Int. J. Technol. Policy Manag. 2006, 6, 399-412. [CrossRef]

3. Lee, K.-H.; Cin, B.C.; Lee, E.Y. Environmental Responsibility and Firm Performance: The Application of an Environmental, Social and Governance Model. Bus. Strat. Environ. 2016, 25, 40-53. [CrossRef]

4. Vlachos, P.A.; Theotokis, A.; Panagopoulos, N.G. Sales force reactions to corporate social responsibility: Attributions, outcomes, and the mediating role of organizational trust. Ind. Mark. Manag. 2010, 39, 1207-1218. [CrossRef]

5. Luo, X.; Bhattacharya, C. Corporate Social Responsibility, Customer Satisfaction, and Market Value. J. Mark. 2006, 70, 1-18. [CrossRef]

6. Wu, W.; Liang, Z.; Zhang, Q. Effects of corporate environmental responsibility strength and concern on innovation performance: The moderating role of firm visibility. Corp. Soc. Responsib. Environ. Manag. 2020, 27, 1487-1497. [CrossRef]

7. Williamson, D.; Lynch-Wood, G.; Ramsay, J. Drivers of Environmental Behaviour in Manufacturing SMEs and the Implications for CSR. J. Bus. Ethics 2006, 67, 317-330. [CrossRef]

8. Kozyrev, M.S.; Frolova, E.V.; Medvedeva, N.V.; Ryabova, T.M.; Evstratova, T.A. Environmental protection activities: Government control/regulation and environmental responsibility of business. Ecol. Environ. Conserv. 2017, 23, 596-604.

9. Huang, P.; Zhang, X.; Deng, X. Survey and analysis of public environmental awareness and performance in Ningbo, China: A case study on household electrical and electronic equipment. J. Clean. Prod. 2006, 14, 1635-1643. [CrossRef]

10. He, M.; Chen, J. Sustainable Development and Corporate Environmental Responsibility: Evidence from Chinese Corporations. J. Agric. Environ. Ethic 2009, 22, 323-339. [CrossRef]

11. Lowe, P.; Morrison, D. Bad News or Good News: Environmental Politics and the Mass Media. Sociol. Rev. 1984, 32, 75-90. [CrossRef]

12. Deng, H.; Zheng, X.; Huang, N.; Li, F. Strategic Interaction in Spending on Environmental Protection: Spatial Evidence from Chinese Cities. China World Econ. 2012, 20, 103-120. [CrossRef]

13. Ouyang, Z.; Yao, N.; Hu, X. Crisis spillover of corporate environmental misconducts: The roles of perceived similarity, familiarity, and corporate environmental responsibility in determining the impact on oppositional behavioral intention. Bus. Strat. Environ. 2020, 29, 1797-1808. [CrossRef]

14. Khan, A.; Bibi, S.; Ardito, L.; Lyu, J.; Hayat, H.; Arif, A.M. Revisiting the Dynamics of Tourism, Economic Growth, and Environmental Pollutants in the Emerging Economies-Sustainable Tourism Policy Implications. Sustainability 2020, 12, 2533. [CrossRef]

15. Rahman, N.; Post, C. Measurement Issues in Environmental Corporate Social Responsibility (ECSR): Toward a Transparent, Reliable, and Construct Valid Instrument. J. Bus. Ethics 2011, 105, 307-319. [CrossRef]

16. Heikkurinen, P. Image differentiation with corporate environmental responsibility. Corp. Soc. Responsib. Environ. Manag. 2010, 17, 142-152. [CrossRef] 
17. Shah, K.U. Strategic organizational drivers of corporate environmental responsibility in the Caribbean hotel industry. Policy Sci. 2011, 44, 321-344. [CrossRef]

18. Mindak, M.; Heltzer, W. Corporate environmental responsibility and audit risk. Manag. Audit. J. 2011, 26, 697-733. [CrossRef]

19. García-Sánchez, I.M.; Gallego-lvarez, I.; Zafra-Gómez, J.L. Do independent, female and specialist directors promote eco-innovation and eco-design in agri-food firms? Bus. Strategy Environ. 2021, 30, 1136-1152. [CrossRef]

20. Ong, T.S.; Lee, A.S.; Teh, B.H.; Magsi, H.B. Environmental Innovation, Environmental Performance and Financial Performance: Evidence from Malaysian Environmental Proactive Firms. Sustainability 2019, 11, 3494. [CrossRef]

21. Pfeffer, J.; Salancik, G.R. The External Control of Organizations: A Resource Dependence Perspective; Harper \& Row: New York, NY, USA, 1978.

22. Cromley, R.G.; Leinbach, T.R. External Control of Nonmetropolitan Industry in Kentucky. Prof. Geogr. 1986, 38, 332-342. [CrossRef]

23. García-Sánchez, I.-M.; Gallego-Álvarez, I.; Gomez, J.L.Z. Do the ecoinnovation and ecodesign strategies generate value added in munificent environments? Bus. Strat. Environ. 2020, 29, 1021-1033. [CrossRef]

24. Hassan, A.; Ibrahim, E. Corporate Environmental Information Disclosure: Factors Influencing Companies' Success in Attaining Environmental Awards. Corp. Soc. Responsib. Environ. Manag. 2012, 19, 32-46. [CrossRef]

25. Wahba, H. Does the market value corporate environmental responsibility? An empirical examination. Corp. Soc. Responsib. Environ. Manag. 2008, 15, 89-99. [CrossRef]

26. Russo, M.V.; Fouts, P.A. A Resource-Based Perspective on Corporate Environmental Performance and Profitability. Acad. Manag. J. 1997, 40, 534-559. [CrossRef]

27. Guenster, N.; Bauer, R.; Derwall, J.; Koedijk, K.G. The Economic Value of Corporate Eco-Efficiency. Eur. Financ. Manag. 2011, 17, 679-704. [CrossRef]

28. Li, Z.; Liao, G.; Albitar, K. Does corporate environmental responsibility engagement affect firm value? The mediating role of corporate innovation. Bus. Strat. Environ. 2019, 29, 1045-1055. [CrossRef]

29. Ardito, L.; Dangelico, R.M. Firm Environmental Performance under Scrutiny: The Role of Strategic and Organizational Orientations. Corp. Soc. Responsib. Environ. Manag. 2018, 25, 426-440. [CrossRef]

30. Kim, Y.; Statman, M. Do Corporations Invest Enough in Environmental Responsibility? J. Bus. Ethics 2011, 105, 115-129. [CrossRef]

31. Chuang, S.-P.; Huang, S.-J. The Effect of Environmental Corporate Social Responsibility on Environmental Performance and Business Competitiveness: The Mediation of Green Information Technology Capital. J. Bus. Ethics 2018, 150, 991-1009. [CrossRef]

32. Ottman, J.A. Green Marketing: Opportunity for Innovation; NTC Business Books: Chicago, IL, USA, 1998.

33. McDonald, S.; Oates, C.J. Sustainability: Consumer Perceptions and Marketing Strategies. Bus. Strat. Environ. 2006, 15, 157-170. [CrossRef]

34. Paulraj, A. Environmental motivations: A classification scheme and its impact on environmental strategies and practices. Bus. Strat. Environ. 2009, 18, 453-468. [CrossRef]

35. Bett, H.; Peters, K.; Nwankwo, U.; Bokelmann, W. Estimating consumer preferences and willingness to pay for the underutilised indigenous chicken products. Food Policy 2013, 41, 218-225. [CrossRef]

36. Sama, C.; Crespo-Cebada, E.; Díaz-Caro, C.; Escribano, M.; Mesías, F.J. Consumer Preferences for Foodstuffs Produced in a Socio-environmentally Responsible Manner: A Threat to Fair Trade Producers? Ecol. Econ. 2018, 150, 290-296. [CrossRef]

37. Shrum, L.J.; Lowrey, M.C.M. Buyer characteristics of the green consumer and their implications for advertising strategy. J. Advert. 1995, 24, 71-82. [CrossRef]

38. Rowlands, I.; Scott, D.; Parker, P. Consumers and green electricity: Profiling potential purchasers. Bus. Strat. Environ. 2003, 12, 36-48. [CrossRef]

39. Lafferty, B.A.; Goldsmith, R.E. Corporate Credibility's Role in Consumers' Attitudes and Purchase Intentions When a High versus a Low Credibility Endorser Is Used in the Ad. J. Bus. Res. 1999, 44, 109-116. [CrossRef]

40. Anderson, C.L.; Bieniaszewska, R.L. The role of corporate social responsibility in an oil company's expansion into new territories. Corp. Soc. Responsib. Environ. Manag. 2005, 12, 1-9. [CrossRef]

41. Chichilnisky, G. Sustainable markets with short sales. Econ. Theory 2012, 49, 293-307. [CrossRef]

42. Chivu, R.M. Social and environmental responsibility of the organization in the context of sustainable development. J. Knowl. Manag. Econ. Inf. Technol. 2015, 5, 1-8.

43. Jian, L.; Wang, C.; Na, H.; Saeed, M.A. Research on Relationship between Corporate Environmental Responsibility and Brand Equity-Moderating Effect of Consumer Attitude. Adv. Inf. Sci. Serv. Sci. 2013, 5, 628-634. [CrossRef]

44. Ackerstein, D.S.; Lemon, K.A. Greening the Brand: Environmental Marketing Strategies and the American Consumer. In Greener Marketing: A Global Perspective on Greening Marketing Practice; GSE Research Limited: Stanningley, UK, 2013; Volume 22, pp. 233-254.

45. Vitezic, N. Corporate Reputation and Social Responsibility: An Analysis Of Large Companies In Croatia. Int. Bus. Econ. Res. J. (IBER) 2011, 10, 85-96. [CrossRef]

46. Cho, C.H.; Guidry, R.P.; Hageman, A.M.; Patten, D.M. Do actions speak louder than words? An empirical investigation of corporate environmental reputation. Account. Organ. Soc. 2012, 37, 14-25. [CrossRef] 
47. Hart, S.L.; Ahuja, G. Does it pay to be green? An empirical examination of the reletionship between pollution prevention and firm performance. Bus. Strategy Environ. 1996, 5, 30-37. [CrossRef]

48. Almeida, C.M.V.B.; Rodrigues, A.J.M.; Agostinho, F.; Giannetti, B.F. Material selection for environmental responsibility: The case of soft drinks packaging in Brazil. J. Clean. Prod. 2017, 142, 173-179. [CrossRef]

49. Schumpeter, J. The Theory of Economic Development; Harvard University Press: Cambridge, MA, USA, 1934.

50. Lam, A. Organizational Innovation; Oxford University Press (OUP): Oxford, UK, 2006.

51. Karwa, R.; Solanki, S.K.; Saini, J.S. Heat transfer coefficient and friction factor correlations for the transitional flow regime in rib-roughened rectangular ducts. Int. J. Heat Mass Transf. 1999, 42, 1597-1615. [CrossRef]

52. Berchicci, L.; Dowell, G.; King, A.A. Environmental capabilities and corporate strategy: Exploring acquisitions among US manufacturing firms. Strat. Manag. J. 2012, 33, 1053-1071. [CrossRef]

53. Chiou, T.-Y.; Chan, H.K.; Lettice, F.; Chung, S.H. The influence of greening the suppliers and green innovation on environmental performance and competitive advantage in Taiwan. Transp. Res. Part E Logist. Transp. Rev. 2011, 47, 822-836. [CrossRef]

54. Rennings, K.; Ziegler, A.; Ankele, K.; Hoffmann, E. The influence of different characteristics of the EU environmental management and auditing scheme on technical environmental innovations and economic performance. Ecol. Econ. 2006, 57, 45-59. [CrossRef]

55. Martinez-Conesa, I.; Soto-Acosta, P.; Palacios-Manzano, M. Corporate social responsibility and its effect on innovation and firm performance: An empirical research in SMEs. J. Clean. Prod. 2017, 142, 2374-2383. [CrossRef]

56. Aldas-Manzano, J.; Küster, I.; Vila, N.; Vila-Lopez, N. Market orientation and innovation: An inter-relationship analysis. Eur. J. Innov. Manag. 2005, 8, 437-452. [CrossRef]

57. Low, D.R.; Chapman, R.L.; Sloan, T.R. Inter-relationships between innovation and market orientation in SMEs. Manag. Res. News 2007, 30, 878-891. [CrossRef]

58. Scherer, F. The Link Between Gross Profitability and Pharmaceutical R\&D Spending. Health Aff. 2001, 20, 216-220. [CrossRef]

59. Jian, S.-L.; Hsieh, H.-Y.; Liao, C.-T.; Yen, T.-C.; Nien, S.-W.; Cheng, A.-J.; Juang, J.-L. G G12 Drives Invasion of Oral Squamous Cell Carcinoma through Up-Regulation of Proinflammatory Cytokines. PLoS ONE 2013, 8, e66133. [CrossRef]

60. Patterson, M.L. Innovation as a system: Seeing the linkage between business innovation and revenue growth as a generic, closed Loop system highlights the importance and purpose of innovation investments and the role of executive leaders. Res. Technol. Manag. 2009, 52, 42-51. [CrossRef]

61. Blume-Kohout, M.E.; Sood, N. Market size and innovation: Effects of Medicare Part D on pharmaceutical research and development. J. Public Econ. 2013, 97, 327-336. [CrossRef]

62. Halila, F.; Rundquist, J. The development and market success of eco-innovations. Eur. J. Innov. Manag. 2011, 14, 278-302. [CrossRef]

63. Moffat, A.; Auer, A. Corporate Environmental Innovation (CEI): A government initiative to support corporate sustainability leadership. J. Clean. Prod. 2006, 14, 589-600. [CrossRef]

64. Babiak, K.; Trendafilova, S. CSR and environmental responsibility: Motives and pressures to adopt green management practices. Corp. Soc. Responsib. Environ. Manag. 2011, 18, 11-24. [CrossRef]

65. Trendafilova, S.; Babiak, K. Understanding strategic corporate environmental responsibility in professional sport. Int. J. Sport Manag. Mark. 2013, 13, 1-26. [CrossRef]

66. Chuang, S.-P.; Huang, S.-J. Effects of Business Greening and Green IT Capital on Business Competitiveness. J. Bus. Ethics 2015, 128, 221-231. [CrossRef]

67. Porter, M.E.; van der Linde, C. Green and competitive: Ending the stalemate. Long Range Plan. 1995, 28, 128-129. [CrossRef]

68. Fernandez-Kranz, D.; Santalo, J. When Necessity Becomes a Virtue: The Effect of Product Market Competition on Corporate Social Responsibility. J. Econ. Manag. Strat. 2010, 19, 453-487. [CrossRef]

69. Leal, G.G.; Fa, M.C.; Pasola, J.V. Using environmental management systems to increase firms' competitiveness. Corp. Soc. Responsib. Environ. Manag. 2003, 10, 101-110. [CrossRef]

70. Toshimitsu, T. Effect of a tariff on the environment and welfare: The case of an environmental differentiated duopoly in a Green Market. Jpn. World Econ. 2008, 20, 114-128. [CrossRef]

71. Zhao, L.; Du, J. Certification of Environmental Corporate Social Responsibility Activities in Differentiated Duopoly Market. Math. Probl. Eng. 2017, 2017, 1-7. [CrossRef]

72. Liu, C.-C.; Wang, L.F.; Lee, S.-H. Strategic environmental corporate social responsibility in a differentiated duopoly market. Econ. Lett. 2015, 129, 108-111. [CrossRef]

73. Rugman, A.M.; Verbeke, A. Six cases of corporate strategic responses to environmental regulation. Eur. Manag. J. 2000, 18, 377-385. [CrossRef]

74. Kehbila, A.G.; Ertel, J.; Brent, A.C. Strategic corporate environmental management within the South African automotive industry: Motivations, benefits, hurdles. Corp. Soc. Responsib. Environ. Manag. 2009, 16, 310-323. [CrossRef]

75. Peng, W.; Xin, B.; Kwon, Y. Optimal Strategies of Product Price, Quality, and Corporate Environmental Responsibility. Int. J. Environ. Res. Public Health 2019, 16, 4704. [CrossRef] [PubMed]

76. Thøgersen, J.; Ölander, F. Spillover of environment-friendly consumer behaviour. J. Environ. Psychol. 2003, 23, 225-236. [CrossRef]

77. Thøgersen, J.; Crompton, T. Simple and Painless? The Limitations of Spillover in Environmental Campaigning. J. Consum. Policy 2009, 32, 141-163. [CrossRef]

78. Sui, D.Z. Tobler's First Law of Geography: A Big Idea for a Small World? Ann. Assoc. Am. Geogr. 2004, 94, 269-277. [CrossRef] 
79. Baughn, C.C.; Bodie, N.L.; McIntosh, J.C. Corporate social and environmental responsibility in Asian countries and other geographical regions. Corp. Soc. Responsib. Environ. Manag. 2007, 14, 189-205. [CrossRef]

80. Bai, C.-E.; Ma, H.; Pan, W. Spatial spillover and regional economic growth in China. China Econ. Rev. 2012, 23, 982-990. [CrossRef]

81. Tong, T.; Yu, T.E.; Cho, S.-H.; Jensen, K.; Ugarte, D.D.L.T. Evaluating the spatial spillover effects of transportation infrastructure on agricultural output across the United States. J. Transp. Geogr. 2013, 30, 47-55. [CrossRef]

82. Lambert, D.M.; Brown, J.P.; Florax, R.J.G.M. A two-step estimator for a spatial lag model of counts: Theory, small sample performance and an application. Reg. Sci. Urban Econ. 2010, 40, 241-252. [CrossRef]

83. Gu, J. Spatiotemporal context and firm performance: The mediating effect of strategic interaction. Growth Chang. 2020, 00, 1-26. [CrossRef]

84. Chen, C.-S.; Yu, C.-C.; Hu, J.-S. Constructing performance measurement indicators to suggested corporate environmental responsibility framework. Technol. Forecast. Soc. Chang. 2018, 135, 33-43. [CrossRef]

85. Pavitt, K. Patent statistics as indicators of innovative activities: Possibilities and problems. Scientometrics 1985, 7, 77-99. [CrossRef]

86. Albino, V.; Ardito, L.; Dangelico, R.M.; Petruzzelli, A.M. Understanding the development trends of low-carbon energy technologies: A patent analysis. Appl. Energy 2014, 135, 836-854. [CrossRef]

87. Gu, J. Spatiotemporal dynamics of the patent race: Empirical evidence from listed companies in China. Asian J. Technol. Innov. 2020, 00, 1-28. [CrossRef]

88. Wooldridge, J.M. Introductory Econometrics: A Modern Approach; Cengage Learning: Mason, OH, USA, 2016 ; pp. $191-193$.

89. Wu, J.; Ma, Z. Export Intensity and MNE Customers' Environmental Requirements: Effects on Local Chinese Suppliers' Environment Strategies. J. Bus. Ethics 2014, 135, 327-339. [CrossRef]

90. Lefever, D.W. Measuring Geographic Concentration by Means of the Standard Deviational Ellipse. Am. J. Sociol. 1926, 32, 88-94. [CrossRef]

91. Gong, J. Clarifying the Standard Deviational Ellipse. Geogr. Anal. 2002, 34, 155-167. [CrossRef]

92. Baron, R.M.; Kenny, D.A. The moderator-mediator variable distinction in social psychological research: Conceptual, strategic, and statistical considerations. J. Pers. Soc. Psychol. 1986, 51, 1173-1182. [CrossRef]

93. Li, J.; Lu, Y.; Wang, G.; Jiao, W.; Chen, C.; Wang, T.; Luo, W.; Giesy, J.P. Evaluation and Spatial Diffusion of Health Risk of Persistent Organic Pollutants (POPs) in Soils Surrounding Chemical Industrial Parks in China. Hum. Ecol. Risk Assessment Int. J. 2010, 16, 989-1006. [CrossRef]

94. Ardito, L.; Natalicchio, A.; Petruzzelli, A.M.; Garavelli, A.C. Organizing for continuous technology acquisition: The role of R\&D geographic dispersion. RED Manag. 2017, 48, 165-176. [CrossRef]

95. Dahlmann, F. Between Inertia and Adaptation: State and Evolution of Corporate Environmental Strategy. Ph.D. Thesis, University of Bath, Bath, UK, 2009.

96. Rees, W.E. Economic Development and Environmental Protection: An Ecological Economics Perspective. Environ. Monit. Assess. 2003, 86, 29-45. [CrossRef]

97. Dreger, C.; Reimers, H.-E. Hysteresis in the development of unemployment: The EU and US experience. Span. Econ. Rev. 2009, 11, 267-276. [CrossRef]

98. Congregado, E.; Golpe, A.A.; Parker, S.C. The dynamics of entrepreneurship: Hysteresis, business cycles and government policy. Empir. Econ. 2012, 43, 1239-1261. [CrossRef]

99. Iii, J.K.R.; Stutts, M.A.; Patterson, L. Tactical Considerations for The Effective use of Cause-Related Marketing. J. Appl. Bus. Res. (JABR) 2011, 7, 58-65. [CrossRef]

100. Mohr, L.A.; Webb, D.J.; Harris, K.E. Do Consumers Expect Companies to be Socially Responsible? The Impact of Corporate Social Responsibility on Buying Behavior. J. Consum. Aff. 2001, 35, 45-72. [CrossRef]

101. Chen, Y.-S. The Driver of Green Innovation and Green Image-Green Core Competence. J. Bus. Ethics 2008, 81, 531-543. [CrossRef] 